\title{
Iron absorption from rice meals cooked with fortified salt containing ferrous sulphate and ascorbic acid
}

\author{
BY M. H. SAYERS, S. R. LYNCH, R. W. CHARLTON \\ AND T. H. BOTHWELL \\ South African MRC Iron and Red Cell Metabolism Unit, \\ Departments of Medicine and Pharmacology, University \\ of the Witwatersrand, Fohannesburg, South Africa \\ AND R. B. WALKER \\ Department of Botany, University of Washington, Seattle, USA \\ AND FATIMA MAYE'T \\ Department of Medicine, University of Natal, Durban, South Africa \\ (Received 24 July 1973-Accepted 29 October 1973)
}

\footnotetext{
I. Iron absorption from rice-containing meals was measured by red cell utilization of radioactive $\mathrm{Fe}$ in sixty-six voluntcer multiparous Indian women.

2. In all the studies sait added during the cooking process was used as the carrier for supplemental inorganic Fe and ascorbic acid.

3. Intrinsic $\mathrm{Fe}$ in the rice and supplementary inorganic $\mathrm{Fe}$ were absorbed to the same extent, with a wide range of absorption values.

4. There was a striking difference between the mean absorption of a $3 \mathrm{mg}$ dose of ferrous Fe given to fasting subjects in a solution containing $30 \mathrm{mg}$ ascorbic acid and that of $\mathrm{Fe}$ in a rice meal ( $48 \cdot 7$ and $3.5 \%$ respectively).

5. When ascorbic acid was added during cooking there was a threcfold increase in the absorption of both intrinsic Fe and supplementary Fe when a sufficient quantity (6o mg) was present.

6. It is concluded that the $\mathrm{Fc}_{\mathrm{c}}$ nutrition of rice-eating communities could be improved significantly by the addition of ascorbic acid to the diet.
}

Although there is evidence to suggest that the iron content of predominantly vegetable diets is often adequate (Ramalingaswami \& Patwardhan, r949; Apte \& Iyengar, 1970), its availability for absorption is poor (Hussain, Walker, Layrisse, Clark \& Finch, 1965; Layrisse, Cook, Martinez-Torres, Roche, Kuhn, Walker \& Finch, 1969; Ashworth, Milner \& Waterlow, I973). Lack of available Fe is therefore an important factor in the pathogenesis of Fe deficiency in populations subsisting on diets in which the staple foodstuffs are vegetables. Improvement of Fe nutrition by dietary supplementation with inorganic $\mathrm{Fe}$ in various forms has produced disappointing results (Elwood, 1968; Layrisse, Martinez, Cook, Walker \& Finch, 1973), and it has become increasingly apparent that the poor absorption of both the intrinsic vegetable $\mathrm{Fe}$ and the supplementary $\mathrm{Fe}$ is due to the presence in these staple foodstuffs of substances, e.g. phytates, which inhibit Fe absorption. On the other hand, there is evidence that absorption may be increased if potentiating factors are present in the diet. For example, the addition of ascorbic acid to maize porridge before boiling increases the absorption of not only the intrinsic Fe but also supplementary inorganic $\mathrm{Fe}$ (Sayers, Lynch, 
Jacobs, Charlton, Bothwell, Walker \& Mayet, 1973). It has been suggested that its failure to produce a similar effect when baked into whole-wheat bread is related to its destruction by the high temperatures required for baking.

Because rice is an important staple food that is prepared by boiling, we investigated the effect of ascorbic acid supplementation on Fe absorption from rice-based meals. In these studies cooking salt $(\mathrm{NaCl})$ was used as the carrier for both supplemental $\mathrm{Fe}$ and ascorbic acid.

\section{EXPERIMENTAL}

Sixty-six Indian housewives living in Durban and belonging to a low socio-economic group were studied. They were aged between 35 and $5^{\circ}$ years (mean $3^{8}$ years) and had each had at least three children. The diet of these people is largely made up of cereal foodstuffs, and Fe-deficiency anaemia has previously been shown to be common among them (Mayet, Adams, Moodley, Kleber \& Cooper, 1972). Written consent was obtained from all subjects after the nature of the investigation had been fully explained to them.

The absorption of Fe from a traditional meal of rice with dhal sauce (made from split pulses), or rice with potato and onion soup, was studied. In some experiments rice intrinsically labelled with ${ }^{55} \mathrm{Fe}$ by hydroponic culture (Hussain et al. 1965; Layrisse et al. 1969 ) was mixed with carrier rice to provide $7.0 \mu \mathrm{Ci} /$ subject, and the absorption of the ${ }^{55} \mathrm{Fe}$ was compared with that of $2 \cdot 5 \mu \mathrm{Ci}{ }^{59} \mathrm{Fe}$ added as $\mathrm{FeSO}_{4} \cdot 7 \mathrm{H}_{2} \mathrm{O}$ during cooking. In other studies two meals were eaten on consecutive days, the $\mathrm{FeSO}_{4} \cdot 7 \mathrm{H}_{2} \mathrm{O}$ added during cooking being labelled with $7 \cdot 0 \mu \mathrm{Ci}{ }^{55} \mathrm{Fe}$ on the rst morning and with $2.5 \mu \mathrm{Ci}{ }^{59} \mathrm{Fe}$ on the 2 nd morning. Before each study the subjects were weighed and blood was taken for haematological measurements. The meals were eaten after an overnight fast. Water was allowed $a d l i b$. during the meal and for $4 \mathrm{~h}$ afterward, but no other food or drink was consumed during this time. A blood sample was collected $14 \mathrm{~d}$ later, after an overnight fast, for determination of its ${ }^{55} \mathrm{Fe}$ and ${ }^{59} \mathrm{Fe}$ content. Immediately afterwards $150 \mathrm{ml}$ of a freshly prepared solution containing $30 \mathrm{mg}$ ascorbic acid and $3 \mathrm{mg} \mathrm{Fe}$ as $\mathrm{FeSO}_{4} .{ }_{7} \mathrm{H}_{2} \mathrm{O}$ labelled with $3.5 \mu \mathrm{Ci}{ }^{59} \mathrm{Fe}$ was drunk. After a further $14 \mathrm{~d}$ a second blood sample was collected and its ${ }^{59} \mathrm{Fe}$ activity measured. The absorption of this 'reference' Fe salt, which gave a measure of the absorption capacity of each individual, was then determined by difference.

We calculated that if the whole of each test dose had been retained, the total radiation dose averaged over a period of 13 weeks would have been approximately $25 \%$ of the permissible whole body burden for continuous exposure in the case of ${ }^{59} \mathrm{Fe}$ and $0.5 \%$ in the case of ${ }^{55} \mathrm{Fe}$ (International Commission for Radiation Protection, 1960).

\section{Preparation of the meals}

Sufficient rice was weighed out to provide $100 \mathrm{~g}$ dry rice/subject. It was washed in running tap-water and then boiled in two-and-a-half times its weight of tap-water containing $4 \mathrm{~g} \mathrm{NaCl}$ (analytical grade; BDH Chemicals Ltd, Poole, England) per subject until it was soft, usually about $15 \mathrm{~min}$. All cooking was done in aluminium pots. In some studies the added $\mathrm{NaCl}$ contained $4 \mathrm{mg} \mathrm{Fe}$ as $\mathrm{FeSO}_{4} \cdot 7 \mathrm{H}_{2} \mathrm{O}$ (analytical 
grade; BDH Chemicals Ltd) labelled with ${ }^{59} \mathrm{Fe}$ or ${ }^{55} \mathrm{Fe}$ (Radiochemical Centre, Amersham, England). Various amounts of L-ascorbic acid (analytical grade; BDH Chemicals Ltd) were also present in the $\mathrm{NaCl}$ in certain experiments. (The feasibility of using $\mathrm{NaCl}$ in this way was tested by adding $\mathrm{FeSO}_{4} \cdot 7 \mathrm{H}_{2} \mathrm{O}$ and ascorbic acid to $\mathrm{NaCl}$ in the concentrations used in the absorption experiments and leaving the mixture at room temperature in the laboratory. There was no discoloration or change in taste in a period of 6 months and the ascorbic acid content was unchanged.) When the grains were soft, the water was decanted and the rice was allowed to steam for a further $20 \mathrm{~min}$. The cooked rice was divided into equal portions by weight, and either pea dhal or potato and onion soup was added. A portion was retained for the determination of chemical $\mathrm{Fe}$ and radioisotope contents. For technical reasons it was not possible to measure the ascorbic acid content of the rice after cooking. However, previous studies with boiled maize porridge indicate that about two-thirds of an ascorbic acid supplement is still present in the reduced form after cooking (Sayers et al. 1973).

Sufficient dhal was weighed to provide $5^{\circ} \mathrm{g}$ dry weight for each volunteer. It was boiled in four times its weight of water for 30 min with small quantities of tomato, onion and seasoning in the form of tumeric powder and caraway seeds. Curry leaves, garlic and jeera, a spice, were fried and then homogenized with the pea dhal. The final volume consumed by each individual was approximately $200 \mathrm{ml}$.

Sufficient onions and potatoes were weighed out to provide $50 \mathrm{~g}$ dry weight of each vegetable per subject. The onions were fried in oil and then added, with the potatoes, to twice their total weight of water. Pepper and curry leaves were added as seasoning and the mixture was boiled for $20 \mathrm{~min}$. The approximate volume of soup consumed by each individual was $175 \mathrm{ml}$.

\section{Isotope and chemical methods}

Portions of food (I g) and blood samples ( $\mathrm{I} \mathrm{mll}$ ) were prepared for differential radioactive counting using the method of Katz, Zoukis, Hart \& Dern (1964). The quantities of ${ }^{55} \mathrm{Fe}$ and ${ }^{59} \mathrm{Fe}$ in the processed samples were determined in a liquid scintillation spectrometer (Packard Tri-Carb Model 3002) which had a counting efficiency of $3-4 \%$ for ${ }^{55} \mathrm{Fe}$ and approximately $50 \%$ for ${ }^{3 y} \mathrm{Fe}$ at optimal gain and window settings. The scintillant used was Insta-Gel (Packard Instrument Co., Downcrs Grove, Illinois, LSA). Blood samples $(4 \mathrm{ml})$ collected at the beginning and at the end of the 'reference salt' study were counted in a scintillation spectrometer (Packard Autogamma Tri-Carb Model 300I) against suitable standards. The counting efficiency was approximately $20 \%$. The percentage absorption was calculated on the assumption that $100 \%$ of the absorbed radioactivity was in circulation and that the blood volume of each subject was $65 \mathrm{ml} / \mathrm{kg}$ body-weight.

Serum $\mathrm{Fe}$ concentrations were estimated by a modification (Bothwell \& Finch, I962) of the method of Bothwell \& Mallett (1955) in which sulphonated bathophenanthrolene was used as the colour reagent. The unsaturated Fe-binding capacity was determined by the method of Herbert, Gottlieb and Lau (1967). The Fe content of digested samples of food was estimated by a modification (Bothwell $\&$ Finch, 1962) 
Table I. Absorption values for intrinsic iron $\left({ }^{55} \mathrm{Fe}\right.$ ) and extrinsic $\mathrm{Fe}$ (given as $\mathrm{FeSO}_{4}$. ${ }_{7} \mathrm{H}_{2} \mathrm{O}$ labelled with ${ }^{59} \mathrm{Fe}$ ) from rice and vegetable soup meals consumed with and without I00 $\mathrm{mg}$ ascorbic acid by female subjects

\begin{tabular}{|c|c|c|c|c|c|c|c|c|}
\hline \multirow[b]{2}{*}{ Supplement } & \multirow{2}{*}{$\begin{array}{l}\text { Final } \mathrm{Fc} \\
\text { content } \\
\text { of meal } \\
(\mathrm{mg})\end{array}$} & \multirow{2}{*}{$\begin{array}{l}\text { Haemo- } \\
\text { globin } \\
(\mathrm{g} / \mathrm{l})\end{array}$} & \multirow{2}{*}{$\begin{array}{c}\text { Plasma } \\
\text { Fc } \\
(\mathrm{mg} / 1)\end{array}$} & \multirow{2}{*}{$\begin{array}{c}\text { Percentage } \\
\text { saturation } \\
\text { of total } \\
\text { Fe-binding } \\
\text { capacity }\end{array}$} & \multicolumn{3}{|c|}{ Fe absorption $(\%)$} & \multirow{2}{*}{$\begin{array}{c}\text { Ratio, } \\
\text { extrinsic } \\
\text { Fe : } \\
\text { intrinsic } \\
\text { Fe }\end{array}$} \\
\hline & & & & & salt & ${ }^{55} \mathrm{Fe}$ & ${ }^{59} \mathrm{Fe}$ & \\
\hline \multirow{7}{*}{$\begin{array}{l}4 \mathrm{mg} \text { added } \mathrm{Fe} \\
\text { no added } \\
\text { ascorbic acia }\end{array}$} & \multirow[t]{6}{*}{$5 \cdot 5$} & I 34 & $I \cdot 23$ & $33^{2} \cdot$ & $29 \cdot 2$ & 0 & 0.6 & -- \\
\hline & & $r_{40}$ & $0.6 r$ & 16.8 & $29 \cdot 4$ & 0.7 & $x \cdot 2$ & $I \cdot 7$ \\
\hline & & 140 & 0.03 & $3 I \cdot 7$ & 50.6 & $1 \cdot 3$ & $1 \cdot 4$ & $I \cdot I$ \\
\hline & & 90 & 0.44 & $9: 7$ & 643 & $2 \cdot 5$ & $2 \cdot 9$ & $1 \cdot 2$ \\
\hline & & 92 & 0.53 & 10.5 & $45 \cdot 3$ & 3.5 & $5 \cdot 1$ & $\mathrm{I} \cdot 5$ \\
\hline & & 128 & 0.36 & 94 & $75 \cdot 2$ & $4 \cdot \mathrm{I}$ & 43 & $I \cdot I$ \\
\hline & \multicolumn{2}{|c|}{ Mean 12I } & 0.68 & $18 \cdot 6$ & 49.0 & $2 \cdot 0$ & $2 \cdot 6$ & $\mathbf{I} \cdot 3$ \\
\hline \multirow{10}{*}{$\begin{array}{l}4 \mathrm{mg} \text { added Fe } \\
\text { I } 00 \mathrm{mg} \text { added } \\
\text { ascorbic acid }\end{array}$} & \multirow[t]{9}{*}{$6 \cdot 6$} & 107 & $I \cdot 42$ & $50 \cdot 2$ & 10. 8 & 0.9 & $I \cdot 2$ & $\mathrm{I} \cdot 3$ \\
\hline & & I 15 & 0.59 & 140 & $102: 4$ & $r \cdot 8$ & $4 \cdot 3$ & $2 \cdot 4$ \\
\hline & & 148 & $\mathrm{I} \cdot 50$ & - & 40.9 & $5 \cdot 5$ & $7 * 5$ & $I \cdot 4$ \\
\hline & & 102 & 0.37 & $8 \cdot 2$ & $108 \cdot 0$ & $6 \cdot 5$ & $6 \cdot 7$ & $x \cdot 0$ \\
\hline & & 1.32 & 0.98 & $30 \cdot 2$ & $34 \cdot 8$ & $8 \cdot 9$ & 10.2 & $I \cdot 2$ \\
\hline & & I 28 & I. 04 & - & $53 \cdot 9$ & 12.9 & I 2.5 & $1 \cdot 0$ \\
\hline & & 134 & 0.73 & $17 \cdot 5$ & $43 \% 7$ & 15.5 & 18.2 & $x \cdot 2$ \\
\hline & & 128 & $I \cdot 76$ & 40.9 & $89 \cdot 7$ & I 5.5 & $20 \cdot 5$ & $I \cdot 3$ \\
\hline & & 134 & 0.96 & $20 \cdot 3$ & $65 \cdot 9$ & $38 \cdot 8$ & $34^{\circ} \circ$ & 0.9 \\
\hline & \multicolumn{2}{|c|}{ Mean 125} & I. 04 & $25 \cdot 9$ & $6 \mathrm{I} \cdot \mathrm{I}$ & I I $\cdot 8$ & I $2 \cdot 8$ & $\mathrm{I} \cdot 3$ \\
\hline
\end{tabular}

of the method of Lorber (1927). This was necessary since there was some variation in the $\mathrm{Fe}$ content of the foods that were used.

\section{RESULTS}

\section{Comparison of the absorption of intrinsic rice Fe with that of supplemental Fe}

It was first considered necessary to establish whether an Fe salt added to rice during cooking was absorbed to the same degree as was the intrinsic rice Fe. This has been shown to occur with several other staple vegetable foods (Björn-Rasmussen \& Hallberg, 1972; Cook, Layrisse, Martinez-'Torres, Walker, Monsen \& Finch, 1972; Sayers et al. 1973). When six subjects consumed a single meal of rice intrinsically labelled with ${ }^{55} \mathrm{Fe}$, which had been cooked with $\mathrm{NaCl}$ containing $4 \mathrm{mg} \mathrm{Fe}$ as ${ }^{59} \mathrm{FeSO}_{4} \cdot 7 \mathrm{H}_{2} \mathrm{O}$ and the rice was given together with potato and onion soup, the absorption of each isotope was similar; the mean value for the intrinsic label was $2 \cdot 0 \%(\mathrm{SD} \pm \mathrm{I} \cdot 6)$ and for the extrinsic label $2.6 \%(\mathrm{SD} \pm \mathrm{I} \cdot 8)$ (Table $\mathrm{I}$ ). The absorption of the dietary Fe was in marked contrast to the absorption of a reference Fe salt, the mean value for which was $49.0 \%(\mathrm{SD} \pm \mathrm{I} 8 \cdot 5)$.

A second, similar experiment was done using nine subjects; the only difference was the presence in the $\mathrm{NaCl}$ of $100 \mathrm{mg}$ ascorbic acid with $4 \mathrm{mg} \mathrm{Fe}$ as ${ }^{59} \mathrm{FeSO}_{4} \cdot{ }_{7} \mathrm{H}_{2} \mathrm{O}$. The mean value for absorption of intrinsic $\mathrm{Fe}$ in the rice was $\mathrm{rr} \cdot 8 \%(\mathrm{SD} \pm \mathrm{rr} \cdot 5)$ and of the extrinsic label $12.8 \%(\mathrm{SD} \pm \mathrm{IO} \cdot \mathrm{r})$; the value for the reference salt was $6 \mathrm{I} \cdot \mathrm{I} \%(\mathrm{SD} \pm 33 \cdot \mathrm{O})$ (Table I). It was concluded from these two experiments that supplemental $\mathrm{FeSO}_{4}$. 
Table 2. Absorption values for iron in rice meals given with 4 mg supplementary Fe as $\mathrm{FeSO}_{4} \cdot{ }_{7} \mathrm{H}_{2} \mathrm{O}$ with and without $35 \mathrm{mg}$ ascorbic acid to female subjects

(Final Fe content of meal: without ascorbic acid $7.8 \mathrm{mg}$; with ascorbic acid $7.0 \mathrm{mg}$ )

\begin{tabular}{|c|c|c|c|c|c|}
\hline \multirow[b]{2}{*}{$\begin{array}{l}\text { Haemoglobin } \\
\qquad(\mathrm{g} / 1)\end{array}$} & \multirow[b]{2}{*}{$\begin{array}{l}\text { Plasma Fe } \\
\quad(\mathrm{mg} / 1)\end{array}$} & \multirow{2}{*}{$\begin{array}{l}\text { Percentage } \\
\text { saturation } \\
\text { of total } \\
\text { Fe-binding } \\
\text { capacity }\end{array}$} & \multicolumn{3}{|c|}{ Fe absorption $(\%)$} \\
\hline & & & $\begin{array}{c}\text { Reference } \\
\text { salt }\end{array}$ & $\begin{array}{c}\text { Without } \\
\text { ascorbic acid }\end{array}$ & $\begin{array}{c}\text { With } \\
\text { ascorbic acid }\end{array}$ \\
\hline 128 & $I \cdot 30$ & $28 \cdot 5$ & $7 \cdot 4$ & 0.7 & 0.1 \\
\hline 128 & $\mathrm{I} \cdot 55$ & 29.9 & 29.4 & $x \cdot x$ & $2 \cdot 6$ \\
\hline I 16 & $I \cdot 03$ & $29 \cdot 6$ & $74 \cdot 5$ & $2 \cdot 0$ & $7 \cdot 9$ \\
\hline 128 & 0.93 & 20.9 & $10 \cdot 6$ & $2 \cdot I$ & 0.4 \\
\hline 120 & 0.93 & 20.8 & 43.0 & $2 \cdot 8$ & $6 \cdot 6$ \\
\hline \pm 36 & I.05 & $21 \cdot 4$ & $70 \% 7$ & $3 \cdot 4$ & $4 \cdot 8$ \\
\hline I 28 & 0.70 & $23 \cdot 5$ & 10.9 & $5 \cdot 3$ & $I \cdot 6$ \\
\hline II 2 & 0.31 & $6 \cdot 7$ & 102.0 & $6 \cdot 3$ & 13.4 \\
\hline 122 & 0.62 & $17 \cdot 4$ & $6 I \cdot 2$ & $8 \cdot I$ & $7 \cdot 4$ \\
\hline 88 & 0.54 & $10 \cdot 4$ & $101 \cdot 3$ & II 7 & I $5 \cdot 3$ \\
\hline Mean I2I & 0.90 & 20.9 & $5 I \cdot I$ & $4 \cdot 4$ & $6 \cdot 0$ \\
\hline
\end{tabular}

Table 3. Comparison of absorption values for iron added to rice + soup and $F e$ added to rice +dhal meals each containing $4 \mathrm{mg}$ supplementary $\mathrm{Fe}$ as $\mathrm{FeSO}_{4} \cdot{ }_{7} \mathrm{H}_{2} \mathrm{O}$ and $35 \mathrm{mg}$ ascorbic acid, eaten by female subjects

(Final Fe content of meal : rice + dhal $6.2 \mathrm{mg}$; rice + soup $5 \cdot \mathrm{Img}$ )

\begin{tabular}{|c|c|c|c|c|c|}
\hline \multirow[b]{2}{*}{$\mathrm{Hb}(\mathrm{g} / 1)$} & \multirow{2}{*}{$\begin{array}{c}\text { Plasma Fe } \\
(\mathrm{mg} / \mathrm{l})\end{array}$} & \multirow{2}{*}{$\begin{array}{l}\text { Percentage } \\
\text { saturation } \\
\text { of total } \\
\text { Fe-binding } \\
\text { capacity }\end{array}$} & \multicolumn{3}{|c|}{ Fe absorption $(\%)$} \\
\hline & & & Reference salt & Rice + dhal & Rice + soup \\
\hline I 15 & $I \cdot I 8$ & 39.8 & $12 \cdot I$ & 0.2 & 0.5 \\
\hline $12 I$ & - & - & $18 \cdot 9$ & $x \cdot 0$ & 0.3 \\
\hline 132 & $1 \cdot 68$ & $44 \cdot I$ & $31 \cdot 5$ & $I \cdot 4$ & $3 \cdot 2$ \\
\hline 132 & $\mathrm{I} \cdot 84$ & $28 \cdot 2$ & $38 \cdot 9$ & $x \cdot 7$ & $I \cdot 6$ \\
\hline 94 & 0.45 & 9.9 & $39 \cdot 6$ & $2 \cdot 2$ & $4 \cdot 4$ \\
\hline I 18 & 0.47 & $9 \cdot 6$ & $34^{\circ} 6$ & $3 \cdot 1$ & $7 \cdot 3$ \\
\hline 97 & 0.54 & II 5 & 60.9 & $3 \cdot 3$ & 44 \\
\hline IOI & $0.3^{8}$ & $8 \cdot 6$ & $103 \cdot 8$ & $3 \cdot 3$ & $23 \cdot 4$ \\
\hline 70 & 0.43 & $9^{\circ} 4$ & 50.9 & $5^{\circ}$ & $7 \cdot 1$ \\
\hline 94 & 0.34 & $8 \cdot 9$ & $60 \cdot 7$ & $5 \cdot 0$ & $8 \cdot 4$ \\
\hline 112 & 0.62 & $15{ }^{\circ} 9$ & $58 \cdot 1$ & $5 \cdot 4$ & I I 2 \\
\hline 120 & 0.72 & I 4.8 & $26 \cdot 7$ & $6 \cdot 3$ & $7 \cdot 4$ \\
\hline an $r 09$ & 0.79 & $18 \cdot 2$ & 4477 & $3 \cdot 2$ & $6 \cdot 6$ \\
\hline
\end{tabular}

${ }_{7} \mathrm{H}_{2} \mathrm{O}$ with or without added ascorbic acid was absorbed to the same extent as the intrinsic $\mathrm{Fe}$ in the rice. Furthermore, the addition of roo $\mathrm{mg}$ ascorbic acid increased the absorption of both the added $\mathrm{Fe}$ and the intrinsic $\mathrm{Fe}$. (These conclusions only hold if the intrinsically labelled rice is properly cooked. In a preliminary study using nine subjects, Fe absorption was measured when the rice was prepared with $35 \mathrm{mg}$ added ascorbic acid. The mean value for absorption of the intrinsic label was significantly less than that for the extrinsic label; the values were $3.0 \%(\mathrm{SD} \pm 2 \cdot 4)$ and $7.4 \%$ $(\mathrm{SD} \pm 4.9)$ respectively $(t=4.24, P<0.005)$. On inspection, some grains of rice were 
Table 4. Absorption values for iron in rice meals given with $4 \mathrm{mg}$ supplementary Fe as $\mathrm{FeSO}_{4} \cdot{ }_{7} \mathrm{H}_{2} \mathrm{O}$ with and without $60 \mathrm{mg}$ ascorbic acid to female subjects

(Final Fe content of meal: without ascorbic acid $5.4 \mathrm{mg}$; with ascorbic acid $5.7 \mathrm{mg}$ )

\begin{tabular}{|c|c|c|c|c|c|}
\hline \multirow[b]{2}{*}{$\begin{array}{l}\text { Hacmoglobin } \\
\qquad(\mathrm{g} / \mathrm{l})\end{array}$} & \multirow[b]{2}{*}{$\begin{array}{c}\text { Plasma Fc } \\
(\mathrm{mg} / \mathrm{l})\end{array}$} & \multirow{2}{*}{$\begin{array}{l}\text { Percentage } \\
\text { saturation } \\
\text { of total } \\
\text { Fe-binding } \\
\text { capacity }\end{array}$} & \multicolumn{3}{|c|}{ Fe absorption $(\%)$} \\
\hline & & & Reference salt & $\begin{array}{l}\text { Without } \\
\text { ascorbic acid }\end{array}$ & $\begin{array}{l}\text { With } \\
\text { ascorbic acid }\end{array}$ \\
\hline 148 & 0.84 & $25 \cdot 2$ & $4 \cdot 9$ & 0.2 & I. \\
\hline 108 & 0.51 & II 9 & $5 I^{\prime} \cdot \mathrm{I}$ & 0.8 & $3 \cdot 6$ \\
\hline $\mathrm{I} 28$ & 0.50 & 10.7 & $8 \cdot 6$ & $I \cdot 9$ & $6 \cdot I$ \\
\hline I34 & 0.82 & $19 \cdot 6$ & $35 \cdot 6$ & $2 \cdot 0$ & 7.7 \\
\hline $12 \mathrm{I}$ & 0.76 & 23.2 & $51^{\prime} \mathrm{I}$ & $3^{3} 6$ & $\times 69$ \\
\hline 87 & 0.35 & $5 \cdot 9$ & $52 \cdot 9$ & $4 \cdot 7$ & 15.3 \\
\hline 108 & 0.53 & $21 \cdot 7$ & $30 \cdot 4$ & 5.4 & $12 \cdot 8$ \\
\hline 121 & 0.46 & 10.5 & $98 \cdot 5$ & $7 \cdot 2$ & $3 r \cdot 4$ \\
\hline Mean IIg & 0.60 & $x 6 \cdot x$ & $4 \pi \cdot 6$ & $3 \cdot 2$ & II'9 \\
\hline
\end{tabular}

obviously incompletely cooked and when these were separated they were found to contain the ${ }^{55} \mathrm{Fe}$. The labelled rice therefore required a longer period of cooking than the carrier rice. Care was taken, therefore, to cook the labelled rice until it was soft.)

Effect of $35 \mathrm{mg}$ ascorbic acid on the absorption of Fe in a rice meal

As the results of the first experiment suggested that the addition of roo $\mathrm{mg}$ ascorbic acid to the diet increased the absorption of $\mathrm{Fe}$ in a rice meal, the effect of smaller doses was studied.

In the first experiment, ten volunteers ate a meal of rice and dhal sauce. On the Ist morning the meal was cooked with $\mathrm{NaCl}$ containing $4 \mathrm{mg}$ iron as $\mathrm{FeSO}_{4} \cdot 7 \mathrm{H}_{2} \mathrm{O}$ and on the and morning the same dose of Fe plus $35 \mathrm{mg}$ ascorbic acid was added. The mean value for absorption of Fe from the rice meal which contained no supplementary ascorbic acid was $4.4 \%(\mathrm{SD} \pm 3.5)$, and the mean absorption of the Fe in the meal with added ascorbic acid was $6 \cdot 0 \%(\mathrm{SD} \pm 5 \cdot 2)$ ('lable 2 ). The difference between the two means was not significant $(t=\mathrm{I} \cdot 52, P>0 \cdot \mathrm{I})$.

There may be one of two reasons for the failure to demonstrate significant increase in Fe absorption at this level of Fe fortification. Though it seemed probable that the dose of ascorbic acid was too low, the possibility that the dhal sauce contained some inhibitory factor not present in the potato and onion soup could not be excluded. A formal comparison was therefore made between the two meals. As before, $4 \mathrm{mg} \mathrm{Fe}$ as $\mathrm{FeSO}_{4} \cdot 7 \mathrm{H}_{2} \mathrm{O}$ and $35 \mathrm{mg}$ ascorbic acid were present in the salt. Twelve subjects consumed the rice with dhal sauce on the ist morning, the $\mathrm{FeSO}_{4} \cdot 7 \mathrm{H}_{2} \mathrm{O}$ being labelled with ${ }^{55} \mathrm{Fe}$, and the rice with soup meal on the 2 nd morning. The isotope label on the 2 d occasion was ${ }^{59} \mathrm{Fe}$. The mean value for $\mathrm{Fe}$ absorption from the meal containing dhal sauce was somewhat less $(3.2 \%, \mathrm{sD} \pm \mathrm{x} \cdot 9)$ than that for absorption from the soup meal $(6 \cdot 6 \%, \mathrm{sD} \pm 6 \cdot 3)$, but the difference was not significant $(t=2 \cdot 15$, $P>0.05)$. The mean value for Fe absorption from the reference salt was $44.7 \%$ $(\mathrm{SD} \pm 24 \cdot 5)$ (Table 3). 
Table 5. Absorption values for iron in rice meals given with 4 mg supplementary Fe as $\mathrm{FeSO}_{4} \cdot 7 \mathrm{H}_{2} \mathrm{O}$ with and without $100 \mathrm{mg}$ ascorbic acid to female subjects

(Final Fe content of meal : without ascorbic acid $7.6 \mathrm{mg}$; with ascorbic acid $6.3 \mathrm{mg}$ )

\begin{tabular}{|c|c|c|c|c|c|}
\hline \multirow[b]{2}{*}{$\begin{array}{l}\text { Haemoglobin } \\
\qquad(\mathrm{g} / 1)\end{array}$} & \multirow[b]{2}{*}{$\begin{array}{c}\text { Plasma } F_{e} \\
(m g / 1)\end{array}$} & \multirow{2}{*}{$\begin{array}{l}\text { Percentage } \\
\text { saturation } \\
\text { of total } \\
\text { Fe-binding } \\
\text { capacity }\end{array}$} & \multicolumn{3}{|c|}{ Fe absorption $(\%)$} \\
\hline & & & Reference salt & $\begin{array}{c}\text { Without } \\
\text { ascorbic acid }\end{array}$ & $\begin{array}{c}\text { With } \\
\text { ascorbic acid }\end{array}$ \\
\hline 148 & $I \cdot 6 I$ & $43 \cdot 2$ & 29.5 & 0.2 & 0.2 \\
\hline 132 & 0.70 & $22 \cdot 7$ & $12 \cdot 7$ & $x \cdot 5$ & $6 \cdot 4$ \\
\hline 120 & $\mathrm{I} \cdot 24$ & $31 \cdot 2$ & $6 \cdot 2$ & $I \cdot 6$ & $7 \cdot 7$ \\
\hline $1 \mathrm{I} 8$ & $I \cdot 56$ & $45 \cdot 4$ & $52 \cdot 8$ & $x \cdot 7$ & $8 \cdot 5$ \\
\hline 87 & 0.26 & 43 & $46 \cdot 2$ & $2 \cdot 5$ & $7 \cdot 6$ \\
\hline 108 & 0.63 & $14 \cdot 0$ & $37 \cdot 9$ & 2.7 & $6 \cdot 3$ \\
\hline I 12 & $1 \cdot 00$ & $24 \cdot 0$ & 13.7 & $3 \cdot 2$ & $6 \cdot 4$ \\
\hline I 8 & 0.48 & 143 & $52 \cdot 7$ & $3 \cdot 4$ & $12 \cdot 7$ \\
\hline 112 & 0.78 & 13.5 & $60 \cdot 3$ & $3 \cdot 7$ & $12 \cdot 3$ \\
\hline 94 & 0.65 & 17.0 & $102 \cdot 3$ & $4 \cdot z$ & II 7 \\
\hline I 10 & 0.43 & $6 \cdot 8$ & $52 \cdot 6$ & $12 \cdot 8$ & $3 \mathrm{I} \cdot 8$ \\
\hline 123 & 0.73 & $15 \cdot 6$ & $67 \cdot 2$ & $13^{-1}$ & 34.4 \\
\hline Mean I I 5 & 0.84 & $2 I^{\prime} 0$ & 44.5 & $4 \cdot 2$ & $12 \cdot 2$ \\
\hline
\end{tabular}

Effect of $60 \mathrm{mg}$ ascorbic acid on the absorption of Fe in a rice meal

As the presence of dhal sauce was apparently insufficient to account for the relatively low absorptions obtained with $35 \mathrm{mg}$ of added ascorbic acid, the effect of adding $60 \mathrm{mg}$ ascorbic acid was studied. This was done with eight volunteers given a rice and soup meal. The addition of $60 \mathrm{mg}$ ascorbic acid significantly increased the percentage absorption of Fe from $3.2(\mathrm{SD} \pm 2.4)$ to II $9(\mathrm{SD} \pm 9 \cdot 7)(t=3.25, P<0.02)$. The mean absorption of the reference salt in the group was $4 \mathrm{I} \cdot 6 \%\left(\mathrm{SD} \pm 29^{\circ} 6\right)$ ('Table 4$)$.

\section{Effect of $100 \mathrm{mg}$ ascorbic acid on the absorption of Fe in a rice meal}

Finally, a study was made of the effect on Fe absorption of increasing the ascorbic acid supplement to $100 \mathrm{mg}$. Eleven volunteers consumed rice meals with potato and onion soup on two successive mornings: on the Ist morning the supplementary ${ }^{55} \mathrm{FeSO}_{4} \cdot{ }_{7} \mathrm{H}_{2} \mathrm{O}$ was added without ascorbic acid; on the 2 nd morning the Fe source was ${ }^{59} \mathrm{FeSO}_{4} \cdot 7 \mathrm{H}_{2} \mathrm{O}$ and $100 \mathrm{mg}$ ascorbic acid were also added. The mean value for $\mathrm{Fe}$ absorption from meals without added ascorbic acid was $4.2 \%(\mathrm{SD} \pm 4 \cdot 2)$, whereas with added ascorbic acid it was $12 \cdot 2 \%$ (SD $\pm 10 \cdot 2$ ); the difference was significant $(t=4.42, P<0.005)$. The mean absorption of Fe from the reference Fe salt was $44.5 \%(\mathrm{SD} \pm 27.0)$ (Table 5 ). It was concluded that $100 \mathrm{mg}$ ascorbic acid were no more effective than $60 \mathrm{mg}$ in increasing $\mathrm{Fe}$ absorption from a rice meal.

\section{DISCUSSION}

Our results indicate that the intrinsic Fe in rice is absorbed to the same extent as is a small quantity of an inorganic $\mathrm{Fe}$ salt consumed at the same time if the rice is well cooked. The results are similar to those obtained for a number of vegetable foodstuffs 
(Björn-Rasmussen \& Hallberg, I972; Cook et al. 1972; Sayers et al. 1973). These results are of both theoretical and practical importance. First, they suggest that the two forms of Fe form a common pool with respect to absorption and, secondly, they indicate that there is little purpose in fortifying a foodstuff that contains strong inhibitors of $\mathrm{Fe}$ absorption. For example, mean values for absorption of intrinsic Fe in rice of less than $\mathrm{x} \%$ have been reported (Layrisse \& Martinez-Torres, I97I); any Fe added to this rice should be similarly absorbed. The situation can be put into better perspective by our results. The subjects studied were multiparous Indian women living in a community where Fe-deficiency anaemia is common. Fe deficiency in the group was confirmed by giving each volunteer a small dose of a ferrous salt; in most of the subjects the values for $\mathrm{Fe}$ absorption were high. However, even in this group of women, absorption of dietary Fe was low, with a mean value of less than $4 \%$ for both intrinsic $\mathrm{Fe}$ in rice and supplementary Fe. Values calculated from these results gave a mean Fe absorption value of less than $0.3 \mathrm{mg}$ from a supplemented meal containing a total of $7 \mathrm{mg}$ Fe. The addition of an adequate amount of ascorbic acid before boiling the rice had a marked effect on $\mathrm{Fe}$ absorption, producing a threefold increase in total Fe absorption. By varying the amount of added ascorbic acid it was possible to show that $60 \mathrm{mg}$ was a satisfactory dose, whereas $35 \mathrm{mg}$ was insufficient. The results of our study together with those obtained with other vegetables (Sayers et al. 1973) suggest that $\mathrm{Fe}$ nutrition of populations subsisting on vegetable diets could be improved significantly if ascorbic acid could be added to the diet.

In our study, common salt $(\mathrm{NaCl})$ was used as the carrier for both the ascorbic acid and ferrous sulphate. Although this study was not primarily concerned with the storage properties of supplemented salt, it was possible to show that both supplements could be added to pure $\mathrm{NaCl}$ without discoloration or change in taste. However, the environment was temperate and it is possible that salt would prove a less satisfactory carrier under hot, humid conditions.

A supplementary study which gave interesting results was the determination of $\mathrm{Fe}$ absorption in each subject by means of a small dose of a reference salt. This was done to measure the $\mathrm{Fe}$ status of individual subjects. The Fe absorption rates were high for most subjects, which showed that they were Fe-deficient. A correlation between these reference $\mathrm{Fe}$ absorptions and the absorption of dietary $\mathrm{Fe}$ has been reported (Cook et al. 1972; Layrisse et al. 1973). We determined correlation coefficients for subjects receiving no ascorbic acid and for those receiving 35,60 or $100 \mathrm{mg}$. The values were: no ascorbic acid $r+0.53, P<0.001 ; 35 \mathrm{mg} r+0.77, P<0.00 \mathrm{I} ; 60 \mathrm{mg} r+0.86$, $P<0.01 ; 100 \mathrm{mg} r+0.29, P>0.1$. In general, these results confirm the usefulness of the measurement of 'reference' salt absorption as a method of defining the $\mathrm{Fe}$ absorption capacity of individual subjects and also its use in comparing results obtained in different laboratories. Also important was the finding that the increase in Fe absorption produced by a given dose of ascorbic acid could be predicted on the basis of the Fe absorption from an unsupplemented meal. The correlations between unsupplemented meals and meals supplemented with different amounts of ascorbic acid were: $35 \mathrm{mg} r+0.76, P<0.01$; $60 \mathrm{mg} r+0.93, P<0.00 \mathrm{I}$; I00 $\mathrm{mg} r+0.98$, $P<0.001$. 
This work was supported in part by grants from the International Atomic Energy Agency, Vienna, and the Atomic Energy Board, South Africa. The authors are grateful to Mrs Shirley Lichtigfeld, Miss Fawzia Khan and Miss Premilla Maharaj for their indispensable assistance.

\section{REFERENCES}

Apte, S. V. \& Iyengar, L. (1970). Am. F. clin. Nutr. 23, 73.

Ashworth, A., Milner, P. F. \& Waterlow, J. C. (1973). Br. F. Nutr. 29, 269.

Björn-Rasmussen, E. \& Hallberg, L. (1972). Am. \%. clin. Nutr. 25, 3 r7.

Bothwell, T. H. \& Finch, C. A. (1962). Iron Metabolism ist ed. p. I8, London: J. and A. Churchill.

Bothwell, 'T. H. \& Mallett, B. (1955). Biochem. F. 59, 599.

Cook, J. D., Layrisse, M., Martinez-Torres, C., Walker, R., Monsen, E. \& Finch, C. A. (1972). F. clin. Invest. 5x, 805 .

Elwood, P. C. (1968). Rep. publ. Hith med. Subj., Lond. no. I I7.

Herbert, V., Gottlieb, C. W. \& Lau, K. S. (r967). 7. nucl. Med. 8, 529.

Hussain, R., Walker, R. B., Layrisse, M., Clark, P.\& Finch, C. A. (1065). Am. I. clin. Nutr. 16, 464. International Commission for Radiation Protection ( 1960$)$. Report of Committee II on Permissible Dose of Internal Radiation 1959. I.C.R.P. Publication no. 2. Oxford: Pergamon Press.

Katz, J. H., Zoukis, M., Hart, W. L. \& Dern, R. J. (I964). F. Lab. clin. Med. 63, 885.

Layrisse, M., Cook, J. D., Martinez-Torres, C., Roche, M., Kuhn, I. N., Walker, R. B. \& Finch, C. A. (1969). Blood 33,430.

Layrisse, M. \& Martinez-Torres, C. (r97I). Prog. Hemat. 7, I37.

Layrisse, M., Martinez, C., Cook, J. D., Walker, R. \& Finch, C. A. (I973). Blood 4r, 333.

Lorber, L. (1927). Biochem. Z. 181, 39x.

Mayet, F. G. H., Adams, E. B., Moodley, T., Kleber, E. E. \& Cooper, S. K. (I972). S. Afr. med. F. 46, 1427 .

Ramalingaswami, R. \& Patwardhan, V. N. (1949). Indian $\tilde{J}$. med. Res. 37, 5 r.

Sayers, M. H., Lynch, S. R., Jacobs, P., Charlton, R. W., Bothwell, T. H., Walker, R. B. \& Mayet, F. (1973). Br. J. Haemat. 24, 209. 